\title{
多変量解析法を用いた動脈硬化性疾患における 血小板機能の動向
}

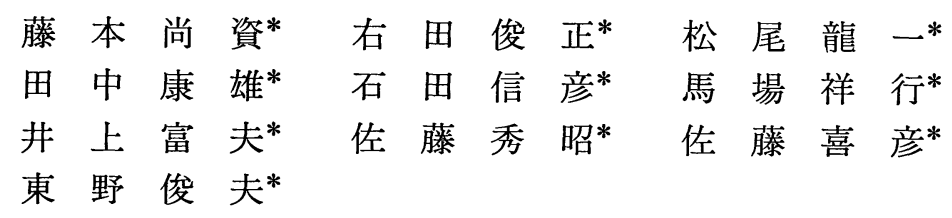

\section{I. 緒 言}

動脈硬化性疾患に打ける危険因子には, 年齢, 血清脂質代謝異常, 糖尿病の有無, 収縮期高血圧 などが知られており, その発生・進展過程には血 液成分の変化, 血行動態, 血管壁代謝異常など 種々の要因が複合的に関与していると推察される. しかしながら，Framingam studyにおいても血液 成分に関しては hemoglobin の上昇についてわず かに言及されているのみである1)。血液成分のな かで, ことに血小板については, Rokitansky に よる “Thrombogenic theory” ならびに Duguid, Ross らの “Repair to injury hypothesis” の提唱に より，血小板が動脈硬化巣の発生に染く関与して いると考えられるようになった，著者らは，虚血 性心疾患例を対象として, 健常者と比較してみる と血小板リン脂質中の phosphatidyl ethanolamine 分画および血小板遊離脂肪酸分画それぞれの構成 脂肪酸のらちアラキドン酸 $\left(\mathrm{C}_{20: 4}\right)$ 比が上昇し, 血漿中でのそれは低下している傾向を認め, 血小 板内プロスタグランジン代謝過程の異常を示唆す る結果を得てすでに報告した ${ }^{2)}$. そこで今回, 各 種血小板機能検查を施行し, 動脈硬化性疾患にお ける血小板機能の動向を検討した. さらにこれら 諸検查值に影響を及ぼすと推定される患者個々の 危険因子との関係を主として多変量解析法を用い

* 杏林大学医学部高龄医学教室
て分析し, 得られた検查值予測式をその後の症例 に連続適用してみたところ比較的良好な成績が得 られたので報告する.

\section{II. 対象ならびに方法}

\section{1. 対 象}

動脈硬化群として労作性狭心症 (EA) 33 例平均 年齢 65.9 19.3 歳, 心筋梗塞 (MI) 32 例平均年齢 $63.7 \pm 11.0$ 歳, 脳梗塞 (CI) 25 例平均年齢 $68.7 \pm$ 9.4 歳計 90 例を選びこれらを血小板機能検查值予 測式を求める A 群とし, その後の EA 10 例平均 年齢 $68.5 \pm 6.2$ 歳, MI 10例平均年齢 $66.0 \pm 8.4$ 歳, CI 10例平均年齢 $67.0 \pm 8.4$ 歳計 30 例を B 群とし て, A 群で求めた予測式の妥当性を検討する対象 とした. EA は非発作時で発作後約 1 週間経過し たものとし，MI·CI は発症約 2 か月後で臨床的 に安定した時期にあるものとした. いずれも血小 板機能に影響を及ぼすと思われる薬剤は使用して いない. 診断基準として EA は臨床症状に一致し た虚血性心電図所見を有し運動負荷心筋シンチに て虚血性変化を認めたものとし，MI は心電図所 見および心筋シンチ所見, CI は臨床上脳血栓例 で神経学的症状に加え頭部 CT scan の異常所見 から診断した。

対照とした健常群は, 男25例, 女25例, 平均年 齢 $48.3 \pm 3.2$ 歳計 50 例で臨床上動脈硬化症状, 血 清脂質代謝異常, 糖尿病および高血圧などを有し 
ないものとした.

\section{2. 方 法}

採血は前腕正中静脈を用い，注射針尖を通常と 逆に末梢側に向け刺入しサンプル採取を行った.

血清総コレステロール (T-C), トリグリセライ ド (TG) は酵素法, HDL コレステール (HDL-C) はへパリン・マンガン法を用い測定した。 また T-C-HDL-C/HDL-C 比を求め動脈硬化指数 (Atherogenic index: AI) とした.

血小板機能検査としては以下の諸項目について 検討し，測定条件は既報に準じて行った ${ }^{3)}$. すな わち，血小板凝集能は比濁法を用い凝集惹起物質 として $2.9 \times 10^{-6} \mathrm{M}$ Adenosin diphosphate を使用 し, Emmons, Mitchell の方法に従い最大凝集率 を測定した. Thromboxane $\mathrm{B}_{2}\left(\mathrm{TXB}_{2}\right)$, 6-KetoProstaglandin $\mathrm{F}_{1 \alpha}$ (6-Keto-PGF $\mathrm{F}_{1 \alpha}$ ) は HPTLC を 用いた RIA 法により測定し， $\beta$-thromboglobulin ( $\beta$-TG), Platelet factor 4 (PF4) はおのおの Amersham 社製 RIA kit, Dinabott 社製 RIA kit を用 いて測定した.

上記の方法で得られた各血小板機能検査值につ
いて以下の方法で推計学的に検討した。（1）A 群 と健常群との比較. Scheffe の多重比較法を用いた. (2) 多変量解析法による血小板機能検查值予測式 の検討. A 群を用い, 患者個々の危険因子を EA 8 項目, MI 10項目, CI 7 項目を選び予測式を求 めた. (3) 予測式妥当性の検討. $\mathrm{A}$ 群を内部標本 とし多変量解析法で得られた予測式を $\mathbf{B}$ 群の外部 標本にあてはめて，その妥当性を検討した。

\section{III. 成 績}

\section{1. 各種血小板機能検查値}

1）血小板凝集能

健常群および動脈硬化A群における血小板凝集 能の動向を Table 1 に示した. 健常群に比し, EA で危険率 0.0004, MI で危険率 0.0037, CI で危険 率 0.0001 といずれも有意な高值が認められた. 次に各疾患群間で比較検討したが有意差は認めら れなかった。

2) $\mathrm{TXB}_{2}$ 值

健常群および $\mathrm{A}$ 群における $\mathrm{TXB}_{2}$ 值の動向を Table 1 に示した. 健常群に比し, MI で危険率

Table 1 Trend of platelet function values in the group of normal healthy subjects and the group of patients with arteriosclerosis

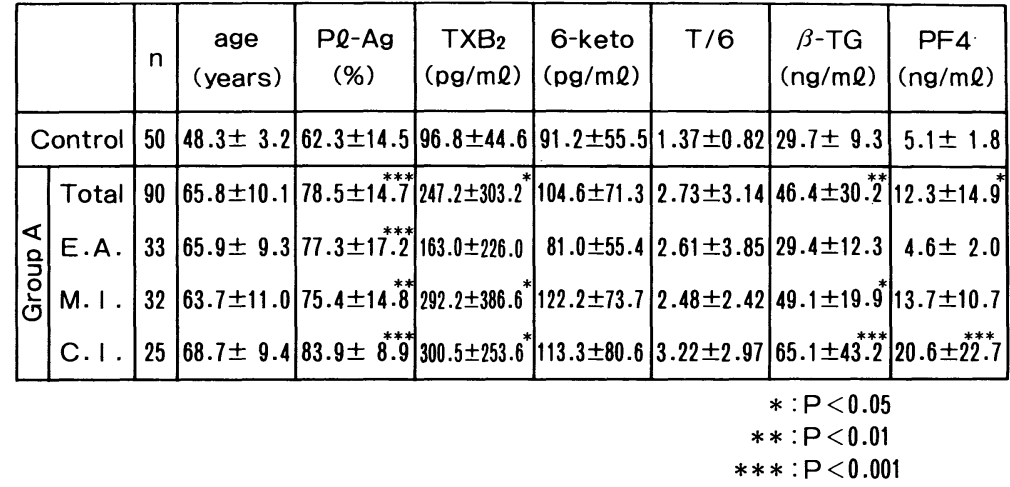

\begin{tabular}{|l|l|l|l|l|l|l|l|}
\hline & Total & 30 & $67.2 \pm 7.5$ & $78.4 \pm 10.5$ & $262.5 \pm 99.9$ & $103.8 \pm 56.8$ & $2.84 \pm 0.90$ \\
\hdashline & E.A. & 10 & $68.5 \pm 6.2$ & $79.2 \pm 8.9$ & $177.7 \pm 50.2$ & $73.4 \pm 40.3$ & $2.84 \pm 1.08$ \\
은 & M. I . & 10 & $66.0 \pm 8.4$ & $76.1 \pm 12.4$ & $315.0 \pm 61.8$ & $123.2 \pm 75.3$ & $2.77 \pm 0.80$ \\
& C. I. & 10 & $67.0 \pm 8.4$ & $80.1 \pm 10.6$ & $294.7 \pm 116.7$ & $114.9 \pm 39.2$ & $2.93 \pm 0.88$ \\
\hline
\end{tabular}

Explanation of abbreviations: Pl-Ag: Platelet aggregation, $\mathrm{TXB}_{2}$ : Thromboxane $\mathrm{B}_{2}$, 6-Keto: 6-KetoProstaglandin $\mathrm{F}_{1} \alpha, \mathrm{T} / 6$ : Ratio of $\mathrm{TXB}_{2}$ to 6-Keto, $\beta$-TG: $\beta$-Thromboglobulin, PF4: Platelet factor 4, E.A.: Effort angina, M.I.: Myocardial infarction, C.I.: Cerebral infarction, P: Significance of difference. Values are mean \pm SD. 
0.0367，CI で危険率 0.0495 と有意な高值を認め たが， EA では明らかでなかった. 次に各疾患群 間で比較検討したが有意差は認められなかった。

3) 6-Keto-PGF ${ }_{1 \alpha}$ 值

健常群および A 群における 6-Keto-PGF 小 $_{1 \alpha}$ 值 の動向を Table 1 に示した. 健常群と比較し, い ずれの疾患群でも有意差は認められなかった. 次 に各疾患群間で比較検討したが有意差は認められ なかった.

4) $\mathrm{TXB}_{2} / 6-$ Keto-PGF ${ }_{1 \alpha}$ 比

健常群およびA群における $\mathrm{TXB}_{2} / 6-$ Keto-PGF $1 \alpha$ 比の動向を Table 1 に示した. 健常群に比し, い ずれの疾患群でも有意差は認められなかった. 次 に各疾患群間で比較検討したが有意差は認められ なかった.

\section{5) $\beta$-TG 值}

健常群および $\mathrm{A}$ 群における $\beta$-TG 值の動向を Table 1 に示した. 健常群に比し MI で危険率 0.0266, CI で危険率 0.0001 と有意な高值が認め られたが，EA では明らかでなかった．次に各疾 患群間で比較検討すると， EA に比べ CI では危 険率 0.0001 と有意な高值を認めた.

\section{6) PF4 值}

健常群および $\mathrm{A}$ 群における $\mathrm{PF} 4$ 值の動向を Table 1 に示した. 健常群に比し CI で危険率 0.0001 で有意な高值を認めたが EA, MI では明ら かでなかった．次に各疾患群間で比較検討すると， $\mathrm{EA}$ に比べ CI で危険率 0.0002 と有意な高值が認 められた。

7) 各種血小板機能検查值相互の関係

血小板凝集能, $\mathrm{TXB}_{2}, 6-\mathrm{Keto}-\mathrm{PGF}_{1 \alpha}, \mathrm{TXB}_{2} /$ 6-Keto-PGF F $_{1 \alpha}$ 比， $\beta$-TG および PF4 各検查值間 の相互関係を検討し Table 2 に示した. 健常群お よび各疾患群とも, $\mathrm{TXB}_{2}$ 值と $\mathrm{TXB}_{2} / 6-$ Keto$\mathrm{PGF}_{1 \alpha}$ 比, $\beta-\mathrm{TG}$ 值と PF4 值との間に良い正相関 が認められたが，それ以外の関連は認められなか った.

2. 多変量解析法による血小板機能検査値の 検討

1) 単相関係数および偏相関係数

血小板凝集能， $\mathrm{TXB}_{2}$ ，6-Keto-PGF ${ }_{1 \alpha} ， \mathrm{TXB}_{2} /$ 6-Keto-PGF 1 $_{1 \alpha}$ 比の各検查值に関連のある因子と
Table 2 Mutual relationship of various platelet function values in the group of normal healthy subjects and the group of patients with arteriosclerosis

\begin{tabular}{|c|l|l|l|l|l|}
\hline$r$ & Control & \multicolumn{1}{|c|}{ Total } & E.A. & M. I . & C. I \\
\hline TXB 2 vs TXB $2 / 6$-keto & $0.400^{* *}$ & $0.639^{* * *}$ & $0.524^{* *}$ & $0.929^{* * *}$ & $0.660^{* * *}$ \\
$\beta$-TG vs PF 4 & $0.531^{* * *}$ & $0.907^{* * *}$ & $0.822^{* * *}$ & $0.793^{* * *}$ & $0.933^{* * *}$ \\
\hline \multicolumn{5}{c}{$* *: P<0.01$} \\
$* * *: P<0.001$
\end{tabular}

Explanation of abbreviation: $\mathrm{r}$ : Correlation coefficient. For other abbreviations, see legend of Table 1.

して, EA で性，年齢，収縮期・拡張期血圧， Treadmill 負荷試験, 糖尿病, 左室駆出分画, 動 脈硬化指数, 心不全重症度分類 (NYHA), 胸部 X 線所見 (心胸郭比), 眼底所見 (Sheie 分類, H·S), 心機図による駆出指数 (PEP/ET), T-C, TG, HDL$\mathrm{C}$ の計16項目, MI で性, 年齢, 梗塞部位, 収縮 期 - 拡張期血圧, 糖尿病, 左室駆出分画, Treadmill 負荷試験, 動脈硬化指数, NYHA 分類, 心胸郭 比, 眼底所見 $(H \cdot S), P E P / E T$, 血清 CPK $\cdot L D H \cdot$ $\mathrm{GOT} \cdot \mathrm{GPT} \cdot \alpha$-HBD 各最大值, 36 誘導前胸壁マッ ピング心電図による異常 $\mathrm{Q}$ 波の数 $(\mathrm{nQ})$ および $\mathrm{ST}$ 上昇部分の総和 $(\Sigma \mathrm{ST})$, 血行力学的異常分類 (Forrester 分類), T-C, TG, HDL-C, 喫煙本数, 心 筋梗塞に基因すると思われる心室瘤などの合併症 の有無, 冠疾患予後指数 (Peel, Norris 分類) の 29 項目, CI で性, 年齢, 収縮期・拡張期血圧, 糖尿 病, 梗塞部位, 動脈硬化指数, 心胸郭比, 眼底所 見 $(\mathrm{H} \cdot \mathrm{S}), \mathrm{T}-\mathrm{C}, \mathrm{TG}, \mathrm{HDL}-\mathrm{C}$ の13項目を選び $\mathrm{A}$ 群 を対象として，まず量的データに関して単相関係 数を求めた. しかしながらこれら患者背景要因は 互いに関連をもち独立した変数としての検討は困 難であると考えられた．そこで数量化 I 類を用い て Table 3 に示した項目を全て施行している11例 の EA，14例の MI，16例の CI を対象に偏相関係 数を求めた. Treadmill 負荷試験は Bruce の変法 で行い，糖尿病は $75 \mathrm{~g}$ ブドウ 糖負荷試験で糖尿 病診断基準委員会勧告值により診断し，左室駆出 分画は gated 心プールスキャンを用い測定した. その結果, Tables 4, 5, 6 に示すごとく単相関係数 では各項目と血小板機能検査值との間に明らかな 関連は認められなかったが，偏相関係数を求める 
動脈硬化 Vol. 12 No. 5 December 1984

Table 3 Patients' main individual factors in the group of patients with arteriosclerosis

\begin{tabular}{|c|c|c|c|c|c|}
\hline \multicolumn{2}{|r|}{ E.A. } & \multicolumn{2}{|r|}{ M. I. } & \multicolumn{2}{|r|}{ C. I. } \\
\hline Sex & $M: 9(82) \quad F: 2(18)$ & Sex & $M: 13(93) \quad F: 1(7)$ & Sex & $M: 12(75) \quad F: 4(25)$ \\
\hline Age & $65.9 \pm 9.3$ years & Age & $63.7 \pm 11.0$ years & Age & $68.7 \pm 9.4$ years \\
\hline $\mathrm{BPs}$ & $123.5 \pm 12.1 \mathrm{mmHg}$ & Position & $A: 10(71)$ nonA : $4(29)$ & $\mathrm{BPs}_{\mathrm{s}}$ & $135.1 \pm 21.7 \mathrm{mmHg}$ \\
\hline $\mathrm{BPD}$ & $69.5 \pm 8.9 \mathrm{mmHg}$ & $\mathrm{BPs}$ & $113.6 \pm 21.7 \mathrm{mmHg}$ & $B P_{D}$ & $77.8 \pm 10.3 \mathrm{mmHg}$ \\
\hline Treadmill & $4.3 \pm 2.7$ Mets & $B P_{D}$ & $68.3 \pm 10.2 \mathrm{mmHg}$ & DM & $+: 4(25) \quad-: 12(75)$ \\
\hline DM & $+: 5(46) \quad-: 6(55)$ & DM & $+: 4(29)-: 10(71)$ & Position & $M: 12(75) \quad P: 4(25)$ \\
\hline EF & $66.9 \pm 13.7 \%$ & CPK & $1588.4 \pm 1051.8 \mathrm{mlU}$ & Al & $3.9 \pm 1.0$ \\
\hline Al & $4.7 \pm 1.9$ & EF & $43.2 \pm 17.1 \%$ & & \\
\hline & & Treadmill & 0.6 Mets & & \\
\hline & & A I & $5.9 \pm \quad 2.3$ & & \\
\hline
\end{tabular}

Explanation of abbreviations: M: Male, F: Female, BPs: Systolic blood pressure, BPD: Diastolic blood pressure, DM: Diabetes mellitus, EF: Ejection fraction, AI: Atherogenic index, Position A: Anteroseptal wall, M: Main trunk, P: Penetrating artery, CPK: Creatine phosphokinase. Values are mean \pm SD. For other abbreviations, see legend of Table 1.

Table 4 Simple and partial correlation analyses in clinical findings in effort angina simple correlation matrix

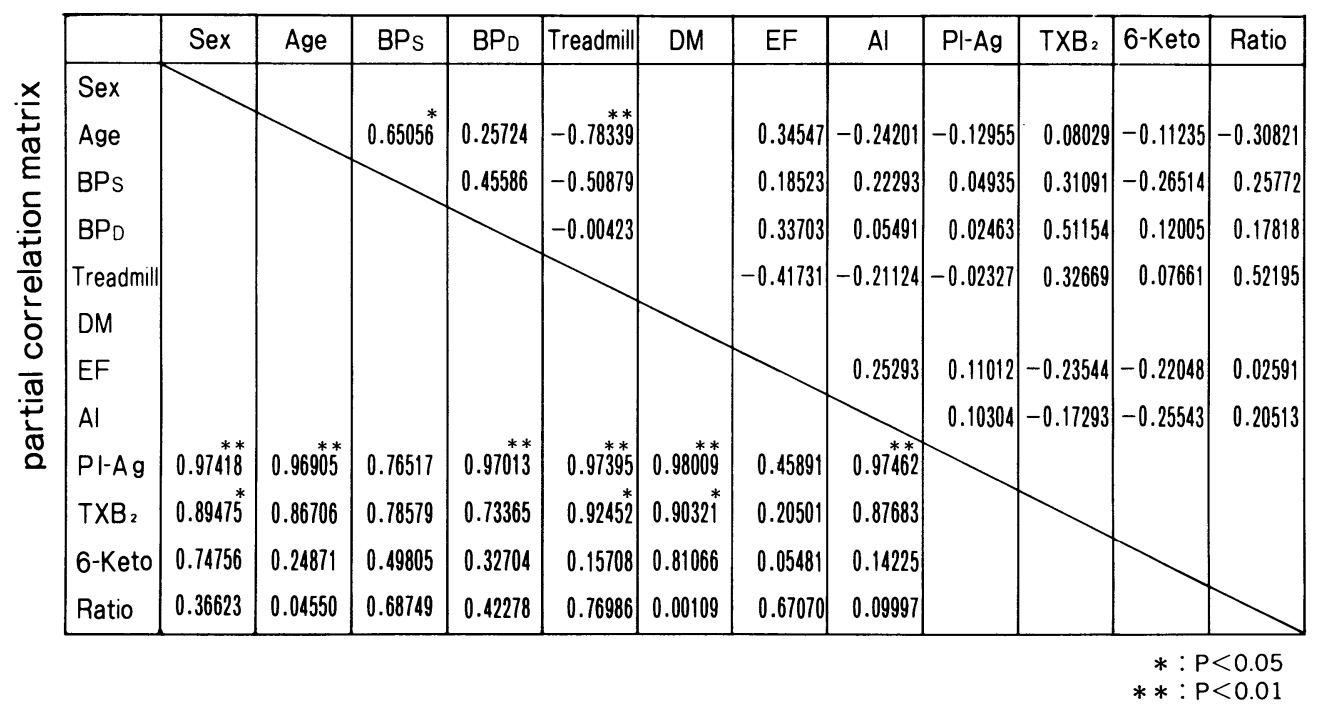

Same abbreviations are used as in Table 3.

と EA において血小板凝集能と性，年噛，拡張期 血圧, Treadmill 負荷試験, 糖尿病, 動脈硬化指数 とに, $\mathrm{TXB}_{2}$ と性, Treadmill 負荷試験, 糖尿病と に高い相関を認め, CI では血小板凝集能と収縮 期血圧，動脈硬化指数とに良い相関が認められた.

2) 血小板機能検查值予測式の検討 血小板機能検查值を求める予測式を作成する目
的で, 各疾患群について前述した項目を使用し回 帰係数を求め, さらに各要因の重みを知るため標 準化偏回帰係数 ( $\beta$-weight) を検討し Tables 7, 8,9 に示した. これにより得られた予測式から導かれ た予測值と実測值との単相関係数を求めたところ, 各疾患群とも良好な寄与率であり，両者の関係を Figs. 1, 2, 3 に示した。 


\section{多変量解析法を用いた動脈硬化性疾患における血小板機能の動向}

Table 5 Simple and partial correlation analyses in clinical findings in myocardial infarction simple correlation matrix

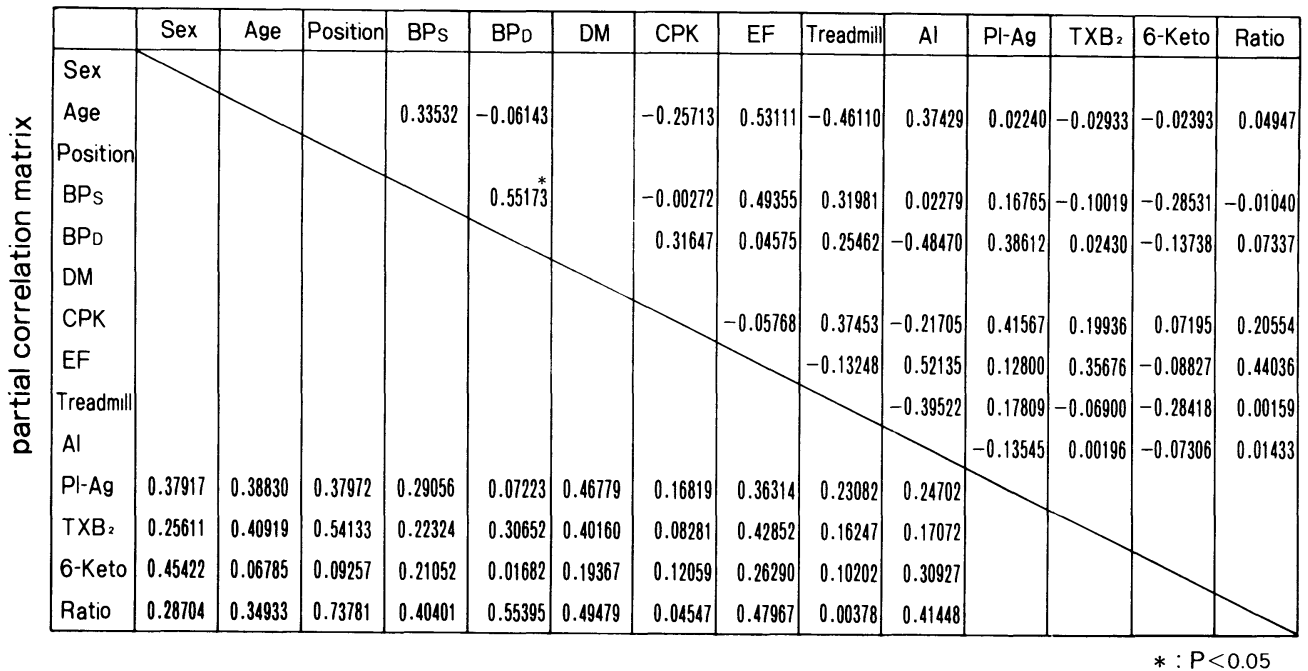

Same abbreviations are used as in Table 3.

Table 6 Simple and partial correlation analyses in clinical findings in cerebral infarction simple correlation matrix

\begin{tabular}{|c|c|c|c|c|c|c|c|c|c|c|c|}
\hline & Sex & Age & BPs & $\mathrm{BPD}$ & DM & Position & $\mathrm{Al}$ & $\mathrm{Pl}-\mathrm{Ag}$ & $\mathrm{TXB}_{2}$ & 6-Keto & Ratio \\
\hline Sex & & & & & & & & & & & \\
\hline Age & & & 0.06362 & 0.07841 & & & -0.21523 & 0.03567 & 0.06115 & -0.01210 & -0.04316 \\
\hline $\mathrm{BPs}$ & & & & 0.46719 & & & -0.23954 & 0.35665 & $-0.51633^{*}$ & -0.06931 & -0.42958 \\
\hline$B P_{D}$ & & & & & & & -0.00476 & -0.27011 & -0.49115 & -0.05616 & -0.37232 \\
\hline $\mathrm{DM}$ & & & & & & & & & & & \\
\hline Position & & & & & & & & & & & \\
\hline Al & & & & & & & & 0.27776 & 0.01292 & 0.00170 & -0.05623 \\
\hline $\mathrm{Pl}-\mathrm{Ag}$ & 0.10111 & 0.17150 & $0.62705^{*}$ & 0.60057 & 0.41839 & 0.58641 & 0.76243 & & & & \\
\hline $\mathrm{TXB}_{2}$ & 0.06654 & 0.07213 & 0.22998 & 0.19348 & 0.20015 & 0.06781 & 0.12265 & & & & \\
\hline 6-Keto & 0.09843 & 0.03582 & 0.05979 & 0.01636 & 0.24043 & 0.25664 & 0.05517 & & & & \\
\hline Ratio & 0.02755 & 0.00825 & 0.20251 & 0.07245 & 0.08750 & 0.01373 & 0.10532 & & & & \\
\hline
\end{tabular}

Same abbreviations are used as in Table 3 .

\section{3) 予測式妥当性の検討}

予測式を求めるために使用した $\mathrm{A}$ 群の内部標本 の分析結果を基に外部標本が正しく推定されてい るか否かを明らかにするため, Table 1 に示した prospective な B 群に使用し検討した. 予測式よ り求められた予測值と B 群の実測值との関係を
Figs. 4, 5, 6 に示した. 血小板凝集能， $\mathrm{TXB}_{2}$ ，6Keto-PGF ${ }_{1 \alpha}, \mathrm{TXB}_{2} / 6-\mathrm{Keto}-\mathrm{PGF}_{1 \alpha}$ 比の順に予測 值と実測值との単相関係数を求めると, EA で $\mathrm{r}=0.78,0.60,0.58,-0.10$, MI で $0.54,-0.28$, $0.51,0.05$, CI で $-0.07,0.83,0.54,-0.007$ とな り比較的満足す心゙き結果が得られた。 
動脤硬化 Vol. 12 No. 5 December 1984

Table 7 Multivariate analysis in effort angina

\begin{tabular}{|c|c|c|c|c|c|c|c|c|c|}
\hline & \multicolumn{2}{|c|}{$\mathrm{Pl}-\mathrm{Ag}$} & \multicolumn{2}{|c|}{$\mathrm{TXB}_{2}$} & \multicolumn{2}{|c|}{ 6-Keto } & \multicolumn{2}{|c|}{ Ratio } \\
\hline & & $\mathrm{RC}$ & $\beta$ weight & $\mathrm{RC}$ & $\beta$ weight & $\mathrm{RC}$ & $\beta$ weight & $\mathrm{RC}$ & $\beta$ weight \\
\hline \multirow[t]{2}{*}{ Sex } & male & 461.72651 & \multirow{2}{*}{5.98653} & -1794.76434 & \multirow{2}{*}{14.33852} & 57.55067 & \multirow{2}{*}{0.82358} & -14.91137 & \multirow[b]{2}{*}{5.82693} \\
\hline & female & 549.33036 & & -2081.68079 & & -118.17282 & & -13.60302 & \\
\hline Age & & -5.26577 & -4.29505 & 16.46842 & 8.32636 & -2.64914 & $\mid-1.96474$ & 0.01001 & 0.25908 \\
\hline \multirow[t]{2}{*}{$\mathrm{BP}$} & s & -0.80813 & -1.25272 & 6.09343 & 5.85511 & 3.00333 & 4.23321 & 0.10541 & 5.18698 \\
\hline & D & 3.22327 & 2.81944 & -6.13816 & -3.32813 & -2.14508 & -1.70609 & -0.06157 & -1.70973 \\
\hline \multicolumn{2}{|c|}{ Treadmill } & -17.59905 & -1.09945 & 70.11232 & 2.71506 & -5.01195 & -0.28470 & 0.80937 & 1.60512 \\
\hline \multirow[t]{2}{*}{ DM } & $(-)$ & -25.57833 & \multirow{2}{*}{0.35030} & 76.92405 & \multirow{2}{*}{0.65302} & 55.17679 & \multirow{2}{*}{0.68710} & 0.00092 & \multirow{2}{*}{0.00040} \\
\hline & $(t)$ & 30.69399 & & -92.30886 & & -66.21215 & & 0.00110 & \\
\hline EF & & -0.17474 & -0.14894 & -0.49972 & -0.26402 & -0.14281 & -0.11067 & 0.05009 & 1.35521 \\
\hline Al & & -20.67307 & -1.29518 & 61.08025 & 2.37227 & 5.24844 & 0.29898 & 0.07813 & 0.15528 \\
\hline \multicolumn{2}{|c|}{$n$} & \multicolumn{2}{|c|}{$0.98532^{* * *}$} & \multicolumn{2}{|c|}{$0.96795^{* * *}$} & \multicolumn{2}{|c|}{$0.89587^{* * *}$} & \multicolumn{2}{|c|}{$0.95168^{* * *}$} \\
\hline
\end{tabular}

$* * *: \mathrm{P}<0.001$

Explanation of abbreviations: RC: Regression coefficient, R: Multiple correlation coefficient, Ratio: Ratio of $\mathrm{TXB}_{2}$ to 6-Keto. For other abbreviations, see legend Table 3.

Table 8 Multivariate analysis in myocardial infarction

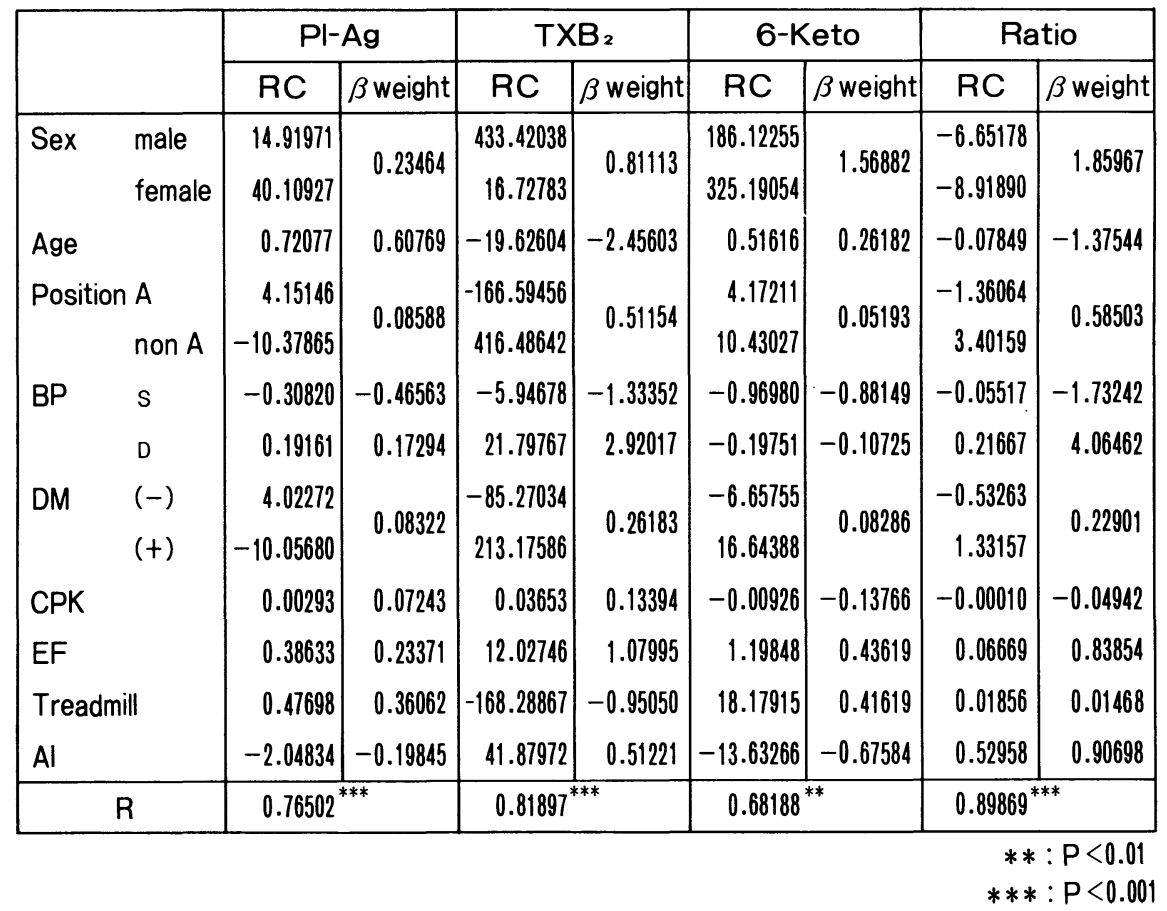

For abbreviations, see legend Table 7. 
多変量解析法を用いた動脈硬化性疾患における血小板機能の動向

Table 9 Multivariate analysis in cerebral infarction

\begin{tabular}{|c|c|c|c|c|c|c|c|c|c|}
\hline & \multicolumn{2}{|c|}{$\mathrm{Pl}-\mathrm{Ag}$} & \multicolumn{2}{|c|}{$\mathrm{TXB}_{2}$} & \multicolumn{2}{|c|}{ 6-Keto } & \multicolumn{2}{|c|}{ Ratio } \\
\hline & & $\mathrm{RC}$ & $\beta$ weight & $\mathrm{RC}$ & $\beta$ weight & $\mathrm{RC}$ & $\beta$ weight & $\mathrm{RC}$ & $\beta$ weight \\
\hline \multirow[t]{2}{*}{ Sex } & male & 46.43354 & \multirow{2}{*}{0.54759} & 1626.72191 & \multirow{2}{*}{4.36953} & 195.54999 & \multirow{2}{*}{1.77444} & 16.71952 & \multirow{2}{*}{3.74406} \\
\hline & female & 43.88869 & & 1704.33617 & & 228.18264 & & 17.16400 & \\
\hline Age & & 0.11446 & 0.09337 & 2.20969 & 0.40021 & -0.31004 & -0.18388 & 0.00349 & 0.05304 \\
\hline \multicolumn{2}{|c|}{ Position M } & 2.02285 & \multirow{2}{*}{0.04188} & 8.82678 & \multirow{2}{*}{0.04057} & 9.76037 & \multirow{2}{*}{0.14692} & 0.02470 & \multirow{2}{*}{0.00952} \\
\hline & $P$ & -6.06856 & & -26.48033 & & -29.28112 & & -0.07411 & \\
\hline \multirow[t]{2}{*}{ BP } & S & 0.41230 & 0.67393 & -5.62520 & -2.04142 & -0.40360 & -0.47962 & -0.06819 & -2.07428 \\
\hline & D & -0.67191 & -0.62955 & -8.19822 & -1.70540 & -0.19258 & -0.13118 & 0.04183 & -0.72936 \\
\hline \multirow[t]{2}{*}{$\mathrm{DM}$} & $(-)$ & 1.43069 & \multirow{2}{*}{0.02962} & -29.48662 & \multirow{2}{*}{0.13554} & -10.12026 & \multirow{2}{*}{0.15233} & 0.17561 & \multirow{2}{*}{0.06766} \\
\hline & $(+)$ & -4.29208 & & 88.45987 & & 30.36077 & & -0.52684 & \\
\hline $\mathrm{Al}$ & & 6.74162 & 0.32103 & -32.86140 & -0.34742 & -4.15853 & -0.14397 & -0.39008 & -0.34567 \\
\hline \multicolumn{2}{|c|}{$n$} & \multicolumn{2}{|c|}{$0.88464^{* * *}$} & \multicolumn{2}{|c|}{$0.62645^{* *}$} & \multicolumn{2}{|l|}{0.34745} & \multicolumn{2}{|l|}{$0.49895^{*}$} \\
\hline & & & & & & & & $\begin{array}{r}*: \\
* *: \\
* * *:\end{array}$ & $\begin{array}{l}<0.05 \\
<0.01 \\
<0.001\end{array}$ \\
\hline
\end{tabular}

For abbreviations, see legend Table 7.
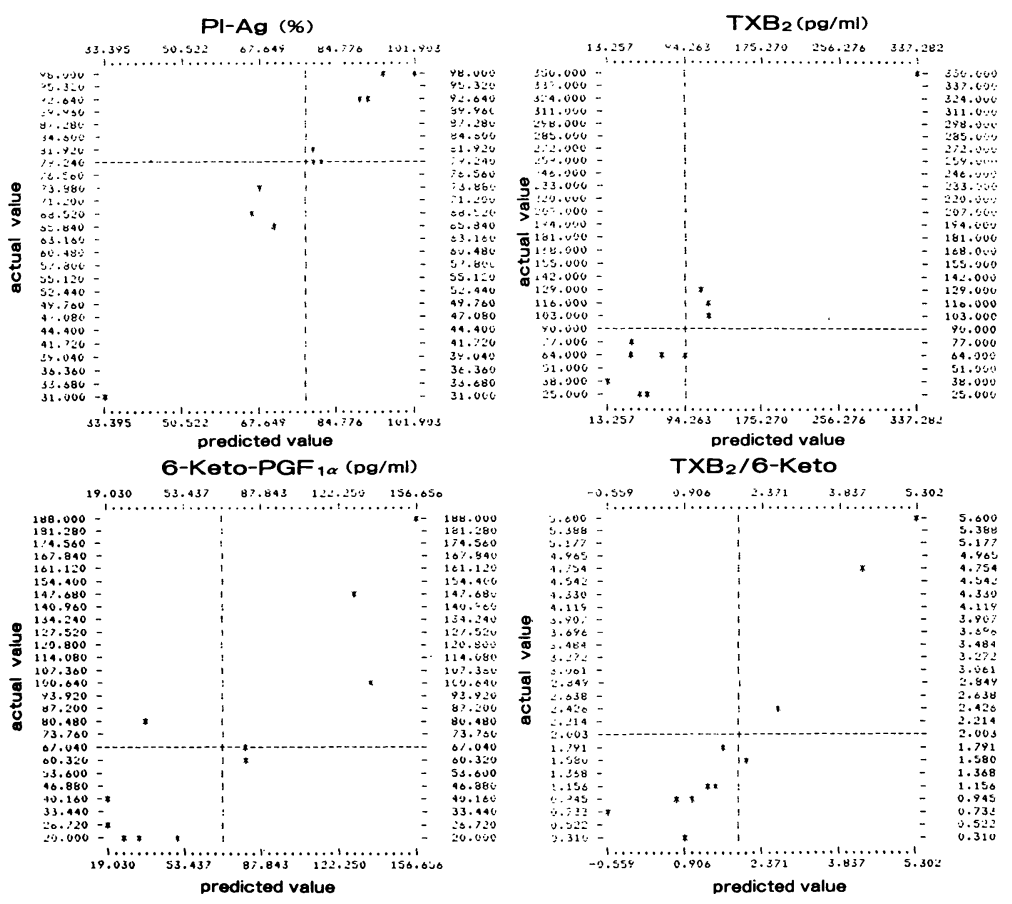

Fig. 1 Relation between predicted and actual values in effort angina in internal samples. For abbreviations, see Table 1. 
動脈硬化 Vol. 12 No. 5 December 1984
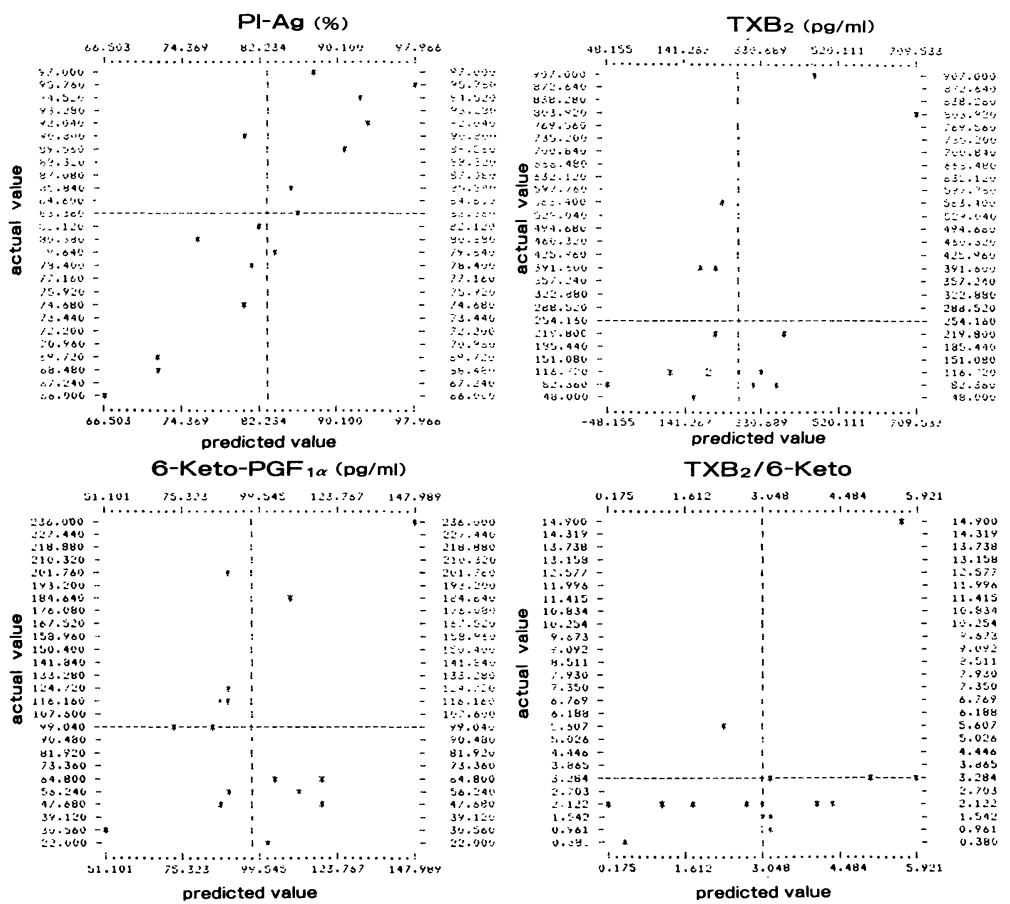

Fig. 2 Relation between predicted and actual values in myocardial infarction in internal samples. For abbreviations, see Table 1.
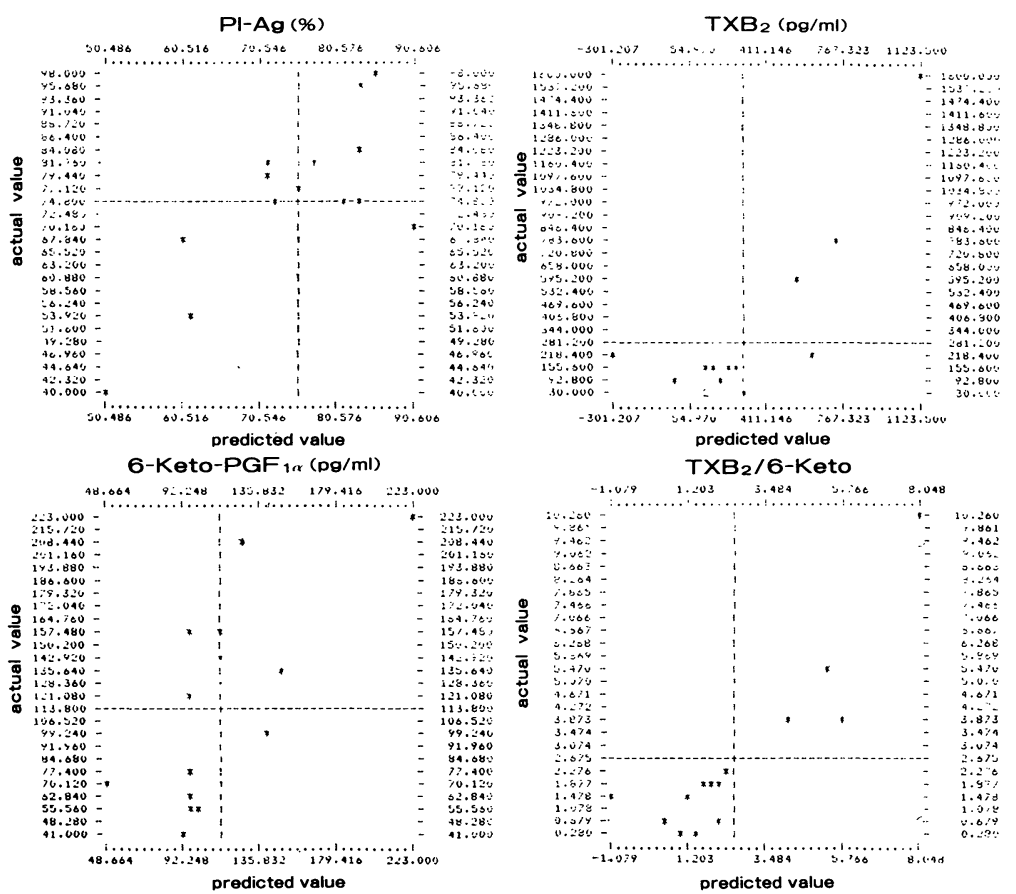

Fig. 3 Relation between predicted and actual values in cerebral infarction in internal samples. For abbreviations, see Table 1. 
P I-A g (\%)

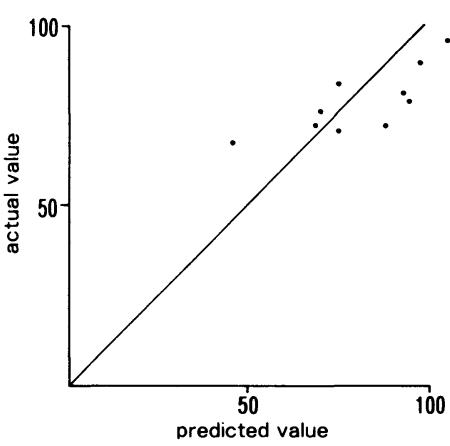

6-keto-PGF $1 \alpha \quad(\mathrm{pg} / \mathrm{ml})$

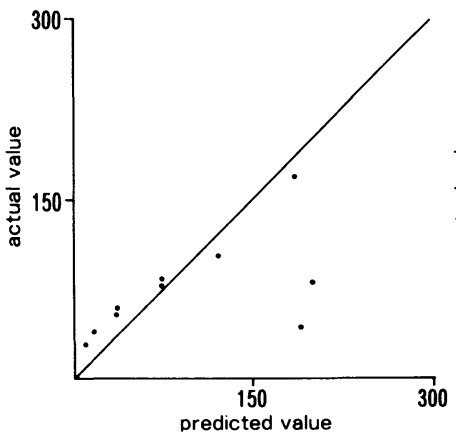

$\mathrm{TXB} 2(\mathrm{pg} / \mathrm{ml})$ ¿ 681

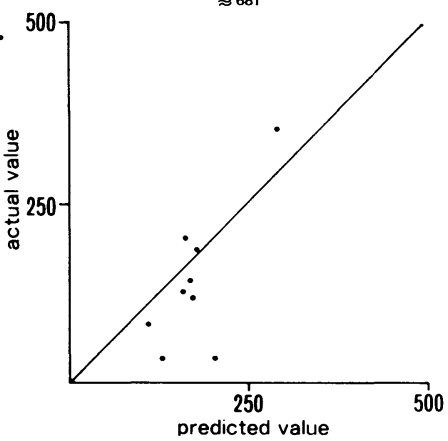

$\mathrm{TXB2} / 6-$ keto

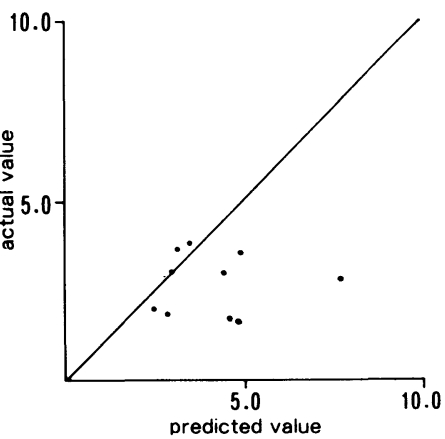

Fig. 4 Relation between predicted and actual values in effort angina in external samples. For abbreviations, see Table 1.

\section{IV. 考案}

血小板は出血時にお扮りる生体防御細胞として働 くが，この傷害血管壁に粘着し凝集する生理的過 程を介して動脈硬化巣の発生・進展に深く関与し ていると考えられている. 血小板が注目される理 由の一つとして，単に血小板血栓を構成するだけ でなく，アテローム巣の形成に関与する血小板由 来のさまざまな生物学的活性物質が明らかにされ つつあるためと思われる。

今回, 動脈硬化性疾患として EA, MI, CI を対 象とし血小板機能の動向を健常者と比較した. こ の際, 以下の諸点に注意をはらい検討した. まずこ のような多群間の差を検定する場合, 二群ずつ組 にして全組み合わせについて検定を行う時, おの おのの有意水準を $\alpha$ とすると全体としての有意水 準は $\alpha$ よ大きくなるとされており，したがって $\mathrm{t}$ 検定では近似的であると言われている.これを 避けるため多重比較法を用いて検討した. 次に対
象とした疾患における血小板機能を検討する場合， 病期の設定時期が問題となる。このため, EA で は最終発作から約 1 週間後と統一し採血を行った。 MI, CI については発症直後ではカテコーラミン などホルモン系の影響が考えられ，またかなりの 症例に投与される血栓融解剂であるキナーゼ製剤 などの時期的影響も考慮し，一方発症後長期間に わたり全く血小板機能に影響を与えない薬剤のみ で加療される症例もまれであるため, これらの影 響を除外する目的で亜急性期とでも称す心゙き約 2 か月後の時点で採血を行った.さらに診断基準の 問題があげられる．すなわち虚血性心疾患におい て心電図上 Minnesota Code の基準が全て冠状動 脈硬化を正しく反映するには限界がある。このた めEA には負荷心筋シンチ所見，MI は心筋シン 于所見を加え診断し得た症例に限定した. CI に ついても全て頭部 CT scan で低吸収域が確認さ れた症例で, かつ心房細動などを有しない臨床上 脳血栓例と思考される症例を選定した。 さらに非 
動脤硬化 Vol. 12 No. 5 December 1984
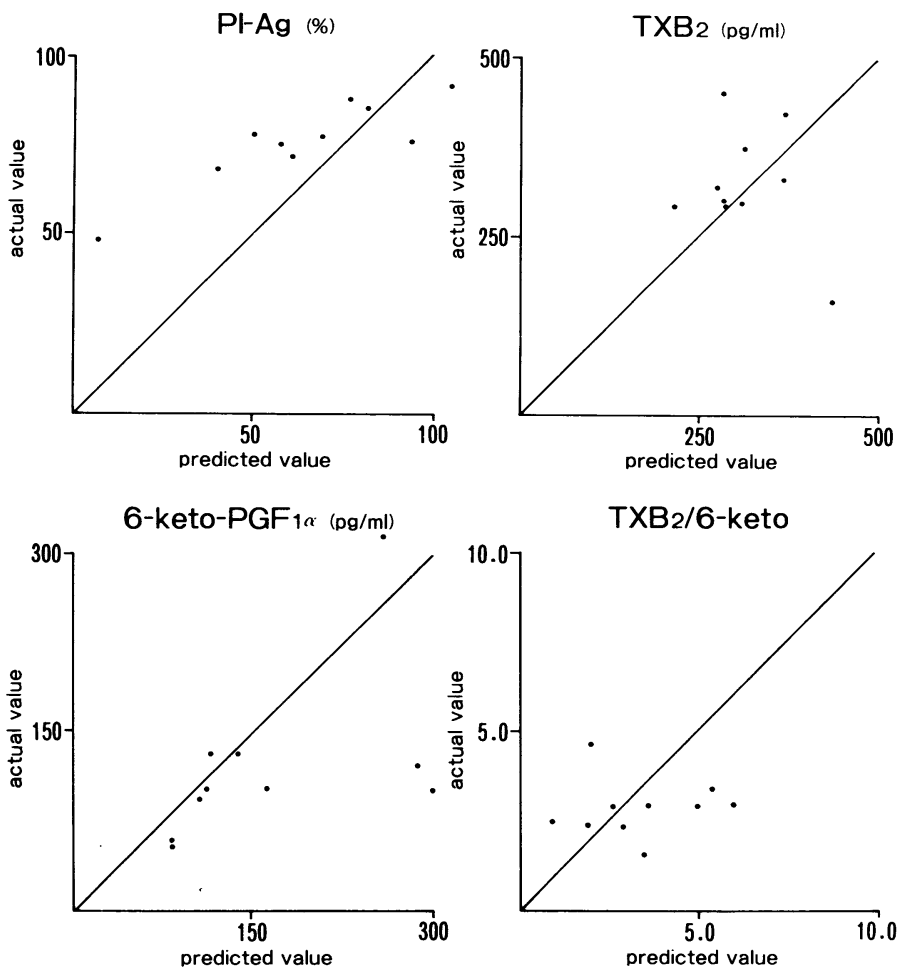

Fig. 5 Relation between predicted and actual values in myocardial infarction in external samples. For abbreviations, see Table 1 .
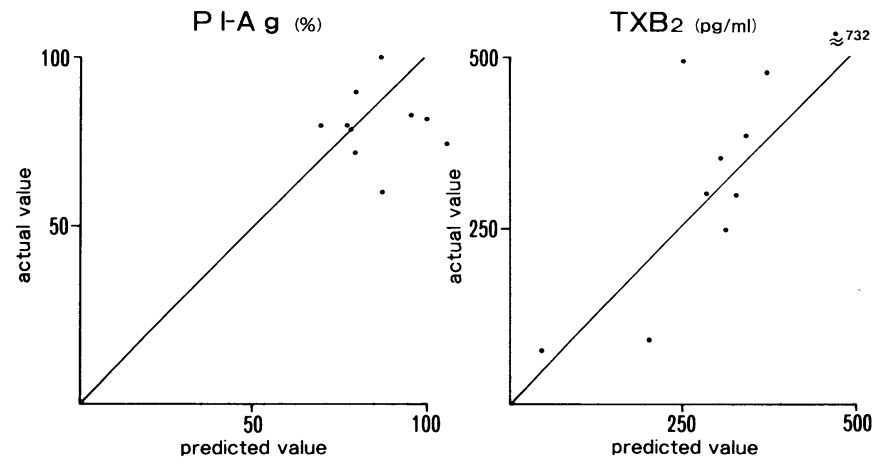

6-keto-PGF $1 \alpha(\mathrm{pg} / \mathrm{ml}$
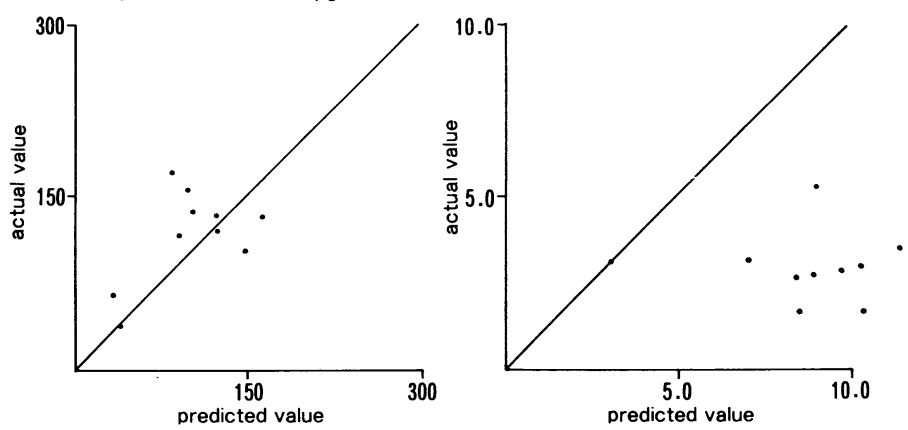

Fig. 6 Relation between predicted and actual values in cerebral infarction in external samples. For abbreviations, see Table 1. 
動脈硬化性の EA, MI，CI が問題となる.しかし ながら年齢その他の条件よりその出現頻度は比較 的少ないと考えられ，全て動脈硬化症を基盤に発 症していると考え検討を行った.

今回の検討では, EA, MI, CI 全ての疾患で血 小板凝集能の元進を認めた．従来の報告では MI 急性期の大部分および CI 急性期では立進を認め ているが一定の結論はまだ得られていない.これ は前述した病期, 診断基準などの相違に加え, 凝 集惹起物質の種類および濃度が報告者により異な りその指標も統一されていないためと思われる.

次に $\mathrm{TXB}_{2}$ 值の動向について述べる. 健常者に 比べ EA では明らかではなかったが MI, CI で有 意な高值を認めた。 Lewy ら ${ }^{4)}$ は，不安定狭心症 を対象に腕動脈と冠状静脈洞の $\mathrm{TXB}_{2}$ 值を検討し, 心筋虚血に TXA 2 が関与していることを初めて 報告した。 また多田ら5) は，EAにおいても末梢 血で $\mathrm{TXB}_{2}$ 值の高值を認めている. しかしながら， Hirsch $ら^{6}$ ) は大動脈, 冠状静脈洞の $\mathrm{TXB}_{2}$ 值を測 定し，不安定狭心症および MI で上昇を認めたが 安定型狭心症では明らかでないとしている. 今回 の非発作時での $\mathrm{EA}$ 例の検討では $\mathrm{TXB}_{2}$ 值に有 意な高值を認めなかったことから，発作時におけ る検討も必要かと思われた. 事実, 多田らは EA 例での pacing 負荷により冠状静脈洞での $\mathrm{TXB}_{2}$ 值上昇を認めている. しかし Hirsch らは pacing 負荷を行っても冠状静脈洞, 大動脈比は高くなら ないと報告している。いずれにせよ，非発作時の $\mathrm{EA}$ に関する末梢血 $\mathrm{TXB}_{2}$ 測定の臨床的意義は限 られたものになると思考された. de Boer ら7 は，MIにおける末梢血 $\mathrm{TXB}_{2}$ 值を検討し，虚血 性心疾患を否定された群と比較してその増加を認 めているが，狭心症群とに差を認めなかったと報 告している. また, Szczekik ら ${ }^{8)}$ は, MI でアラキ ドン酸刺激による $\mathrm{TXB}_{2}$ 産生能を検討し上昇を認 めていることより, 血小板自身の $\mathrm{TXB}_{2}$ 産生能を 検討することも必要と思われる．CI については 末梢血 $\mathrm{TXB}_{2}$ 值を検討しその高值を認めるととも に, その推移は臨床症状と一致するとの報告があ る9).

6-Keto-PGF $1_{\alpha}$ の動向については, 今回の検討 ではいずれの疾患群も健常群に比べ有意差は認め
られなかったものの， EA で低值傾向を示す反面 MI, CI でやや高值を認めた. Prostaglandin $\mathbf{I}_{2}$ $\left(\mathrm{PGI}_{2}\right)$ は他のプロスタグランジン類と異なり肺 循環において分解されないことから， circulating hormone としても考えられているが10), 十分量の $\mathrm{PGI}_{2}$ が流血中にあるとすれば血小板による止血 が困難となることが予想される。このため $\mathrm{PGI}_{2}$ は血管内皮細胞の近傍でのみ適切な濃度を保って いると推察される. また血管内皮細胞による $\mathrm{PGI}_{2}$ 合成能は, 血管部位によっても異なると考 えられている11).したがって今回検討したごとく 末梢血での $\mathrm{PGI}_{2}$ 值の動向が, 直ちに病巣部位で の動態を直接反映しているか否かは検討を要する と思われる. しかしながら $\mathrm{PGI}_{2}$ 産生能は動脈硬 化進展の初期から低下しているとの報告や12), 異 型狭心症例で非発作時すでに末梢血 $\mathbf{P G I}_{2}$ が低下 しているとの報告があり ${ }^{13)}$, さらに脳卒中自然発 症ラットで $\mathrm{PGI}_{2}$ 産生能が低下しているとの報 告 ${ }^{14)}$ から, 動脈硬化や高血圧にさらされた血管壁 ことに内皮細胞の機能低下とも推察される. 今回 MI, CI で健常者に比へ 6-Keto-PGF 值 $_{\alpha}$ が高值傾 向を示した理由は不明であるが，あるいは病変部 以外の末梢血管内皮細胞の PGI $_{2}$ 産生能は代償性 に立進しているとも推測された.

$\beta-\mathrm{TG}, \mathrm{PF} 4$ は健常者に比べ EA では明らかでな かったが， MI，CI で高值が認められた. $\beta$-TG, PF4 はともに血小板 $\alpha$ 顆粒中に存在する血小板 特異蛋白であり，これらは血小板放出反応による 直接的な放出物質として血中に出現するので生体 内血小板凝集惹起物質増加のみならず血管壁内膜 異常, 内皮細胞損傷などをも反映していると考え られ, 動脈硬化性疾患における生体内血栓形成進 行の傾向を示唆していると思考された. 諸家らの 報告では, 各疾患とも高值を認めるもの, 認めな いとするものがあり一定していない.

次に血小板機能検查值相互の関連について述べ る. 今回の検討では $\mathrm{TXB}_{2}$ 值と $\mathrm{TXB}_{2} / 6-$ Keto$\mathrm{PGF}_{1 \alpha}$ 比, $\beta-\mathrm{TG}$ 值と PF4 值との間に良い相関 を認めた. 生体内ことに局所流血中および血管壁 での $\mathrm{TXA}_{2}$ と $\mathrm{PGI}_{2}$ とのバランスが血栓形成, 動 脈硬化の発生・進展に重要であると考えられてい る.しかしながらこのバランスを単純に $\mathrm{TXB}_{2} / 6-$ 
Keto-PGF 1 $_{\alpha}$ 比として表現することは，今回の検 討で明らかなように主に $\mathrm{TXB}_{2}$ の動向を反映して いるにすぎないと思考された. $\beta$-TG と PF4 に良 い相関を認めたことから，どちらか一方の測定で 十分かとも思われる。しかしながら両者とも極端 に高值の場合は測定手技上の問題も考えられるこ と，またどちらか一方のみ増加を認める疾患があ ること，両者の半減期のちがいによりどちらか一 方のみ増加を認める症例があること, 分子量のち がいにより $\beta$-TG が腎機能の影響を受けること,

さらに PF4 は血管内皮細胞にも貯蔵されている 可能性もあることなどより，どちらか一方のみの 測定では十分とはいえず両者合わせての検討によ りその意義解釈を行うべきと思考された.

前述した Szczekik らの報告でも MI で TXA2 生成立進を認めた症例は32例中 13 例であり ${ }^{8)}$, 今 回の検討でも同一疾患例で血小板機能検査值には バラツキが認められ，正常域を示すものもあり， 各疾患の病態に対応する血小板機能関与の多様性 を推察させた. 著者らは, 性, 年齢などの患者要 因, 血圧, 血清脂質などの危険因子を含む患者背 景要因が複雑に関与しその総和として血小板機能 が表現されうると考えた。 そこでまずこれら患者 背景要因と血小板機能検查值との相関関係を検討 したところ, 単相関係数では明らかな関連は認め られなかったが, 各要因相互の影響を除いた偏相 関係数で検討すると明らかな関連を示す要因が認 められた. de Boer ら) は冠状動脈疾患患者にお いて，血小板機能に及ぼす糖尿病の影響を検討し， $\mathrm{TXB}_{2}$ には有意差が認められなかったが $\beta$-TG で は有意差を認めたと報告している. また, 心不全 の有無についても $\mathrm{TXB}_{2}$ では差を認めず $\beta$-TG で 有意差を認めている。 また White ら ${ }^{15)}$ は MI 例 における PF4 について, 性, 年齢, CPK 值, 梗 塞部位, Killip 重症度分類などによる影響を検討 し有意な差は認められなかったと述べている，同 様に Levine $ら^{16)}$ は虚血性心疾患患者における PF4 を検討し, 左室駆出分画, T-C, 狭心症の病 型には影響が認められなかったとしている。また Shio ら ${ }^{17)}$ は CI 例における血小板凝集能は梗塞部 位により影響が認められると報告している。しか しながら，これらの報告は先に述べたように各種
検査值相互の影響を考慮に入れて推計学的に検討 しているわけではない，そこで著者らはさらに多 変量解析法を用いて血小板機能検査值予測式を作 成した. 多変量解析法を用いることにより, 各要 因の重みを計量的に表現できその重要度の順位付 けが可能となった. 寸なわち標準化偏回帰係数を 用いて検討することができる，例えば EA におけ る血小板凝集能では，第 1 に性が次いで年齢が寄 与していることがわかる，このようにして各疾患 群における要因の重要度, 上位 3 位を検討すると, いずれの血小板機能検査においても性，年齢，血 圧が占めていることが認められ，糖尿病，血清脂 質等の重要度はさほど高くなく単独では明確な影 響を及ぼすとはいい難いと思われた. Neri Serneri $ら^{18)}$ は虚血性心疾患患者における血小板機能と 危険因子との関係を重回帰分析法を用いて検討し， 特に影響を与える要因は認められなかったと報告 している.しかしながら検討した要因の中でアラ キドン酸刺激による $\mathrm{TXB}_{2}$ 産生能に影響を与える 因子として, 血糖, TG, 喫煙, T-C, 平均血圧を 示している.さらにこれら要因を用いて血小板機 能検査值を推測することが可能となった. すなわ ち各寄与度の評点を加算することにより，与えら れた症例の血小板機能検査值が求められた. そこ で得られた予測式の妥当性を検討する目的で prospective な症例に連続使用を試みた. 今回検討し た各測定值はカテゴリカルデータではないのでそ の判別的中率を求めることは不可能である. しか し仮に血小板凝集能で $\pm 15 \%, \mathrm{TXB}_{2}$ で士 $50 \mathrm{pg} / \mathrm{ml}$, 6-Keto-PGF ${ }_{1 \alpha}$ で $\pm 25 \mathrm{pg} / \mathrm{m} l, \mathrm{TXB}_{2} / 6-\mathrm{Keto}-\mathrm{PGF}_{1 \alpha}$ で \pm 2 を誤差範囲とすると，それぞれ EA で 70, $60,80,70 \%, \mathrm{MI}$ で $40,50,50,60 \%, \mathrm{CI}$ で 70,50 , $40,10 \%$ の的中率となりほぼ満足できる結果が得 られた. 血小板機能に影響を与える危険因子を検 討した今回の成績において, 個々の因子単独では 関連が弱いが，これらの項目に重みをつけて総合 的に判断すると血小板機能がほぼ正確に推察しう ることが確認された. 現在動脈硬化性疾患におけ る血小板の役割が注目されているが，このような 推計学的手法を用いることにより血小板機能が独 立した危険因子として存在するか否かを明らかに するとともにさらに今後症例数を増し患者背景要 
因の選択についても考慮し，予測式の精度を高め ることが重要であると思考された.

\section{V. 結 論}

動脈硬化群として EA, MI, CI 計90例を内部標 本とし，健常群50例と多重比較法を用い血小板機 能を検討した.さらに多変量解析法を用い血小板 機能検查值予測式を作成し，外部標本30例を対象 にその妥当性を検討し以下の結果を得た.

1）動脈硬化群の EA を除くいずれの疾患にお いても血小板凝集能, $\mathrm{TXB}_{2}, \beta-\mathrm{TG}, \mathrm{PF} 4$ の高值 を認めたが 6-Keto-PGF 依 $_{1}$ では有意差を認めなか った.

2) 血小板機能検査相互の関係は, 健常群およ び動脈硬化群ともに $\mathrm{TXB}_{2}$ と $\mathrm{TXB}_{2} / 6-\mathrm{K}^{2}$ eto-PGF $\mathrm{PG}_{1 \alpha}$ 比， $\beta$-TG と PF4 とに良い相関を認めた.

3）血小板機能検查值に影響を及ぼす患者背景 要因として性, 年齢, 血圧が重要であることが判 明した。

4) 得られた血小板機能予測式を外部標本に用 いたところ，比較的満足す心゙き結果が得られ予測 式妥当性が確認された。

謝辞 : 本研究に御助言をいただいたエーザイ株式会社 医学情報部佐藤啓輔氏の御協力に深謝します.

本論文の要旨は日本動脈硬化学会昭和58年度冬季大会, 第16回日本動脈硬化学会総会にて発表した.

\section{文献}

1) Kannel, W. B., Dawber, T. R., Kagan, A., Rovotskie, N. and Stokes, J.: Factors of risk in the development of coronary heart disease-six-year follow-up experience, the Framingham study. Arch. Int. Med., 55: 33-50 (1961).

2) 佐藤秀昭, 藤本尚資, 馬場祥行, 井上富夫, 横山 登, 佐藤喜彦, 東野俊夫, 米津 昇：虚血性心疾患 における血小板リン脂質脂酸構成比. 動脈硬化, 10: 435-439 (1982).

3）藤本尚資：虚血性心疾患ならびに脳梗塞における Aspirin 投与法の検討——ことに血小板機能を中心 として一一. 動脈硬化, 10: 995-1009 (1982).

4) Lewy, R. I., Wiener, L., Walinsky, p., Lefer, A. M., Silver, M. J. and Smith, J. B.: Thromboxane release during pacing-induced angina pectoris, Possible vasocontrictor influence on the coronary vasculature. Circulation, 61: 1165-1171 (1980).
5) Tada, M., Kuzuya, T., Inoue, M., Kodama, K., Mishima, M., Yamada, M., Inni, M. and Abe, H.: Elevation of thromboxane $\mathrm{B}_{2}$ levels in patients with classic and variant angina pectoris. Circulation, 64: 1107-1115 (1981).

6) Hirsh, P. D., Campbell, W. B., Firth, B. G., Willerson, J. T. and Hills, L. D.: Coronary prostanoids in patients with unstable ischmic heart disease syndrome, $\mathrm{V}$ th International Conference on Prostaglandins, Florence, Italy, p. 271 (1983).

7) de Boer. A. C., Turpe, A. G. G., Butt, R. W., Johnston, R. V. and Genton, E.: Platelet release and thromboxane synthesis in symptomatic coronary artery disease. Circulation, 66: 327-333 (1982).

8) Szczekik, A., Gryglewski, R. J., Musial, J., Grodzinska, L., Serwonska, L., Wojcik-Switek, L. and Marcinkiewicz, E.: Arachidonic acid-induced platelet aggregation and thromboxane $\mathrm{A}_{2}$ generation in patients with coronary heart disease. Acta Biol. Med. Germ., 37: 741-742 (1978).

9）大森啓造, 矢島途好, 沼野藤夫, 前沢秀憲, 小田倉 力：脳卒中患者における血漿 Thromboxane $\mathrm{B}_{2}$ 濃 度について. 脳卒中, 3: 63-68 (1981).

10) Moncada, S., Korbut, R., Bunting, S. and Vane, J. R.: Prostacyclin is a circulating hormone. Nature, 273: 767-768 (1978).

11) Sinzinger, H., Clopath, P., Silberbauer, K. and Winter, M.: Is the variation in the susceptibility of various species to atherosclerosis due to inborn differences in prostacyclin $\left(\mathrm{PGI}_{2}\right)$ formation? Experientia, 36: 321-323 (1980).

12) Sinzinger, H., Silberbauer, K., Feigl, W., Winter, M. and Auerswald, W.: Prostacyclin activity is diminished in different types of morphologically controlled human atherosclerotic lesions. Thromb. Haemost., 42: 803-804 (1979).

13) Kuzuya, T., Tada, M., Ohmori, M., Inui, M., Inoue, M., Abe, H., Yamagishi, M. and Kodama, K.: Altered metabolism of thromboxane $\mathrm{A}_{2}$ and prostaglandin $I_{2}$ in patients with angina pectoris (abstr.). Circulation, 64: IV-143 (1981).

14) Okuma, M., Yamori, Y., Ohta, K. and Uchino, H.: Production of prostacyclin-like substance in strokeprone and stroke-resistant spontaneously hypertensive rats. Prostaglandins, 17: 1-7 (1979).

15) White II, G., C. and Marouf, A. A.: Platelet factor 4 levels in patients with coronary artery disease. J. Lab. Clin. Med., 97: 369-378 (1981).

16) Levine, S. P., Lindenfeld, J., Ellis, J. B., Raymond, N. M. and Krentz, L. S.: Increased plasma concentrations of platelet factor 4 in coronary artery disease, A measure of in vivo platelet activation and secretion. Circulation, 64: 626-632 (1981).

17) Shio, H., Ohtsuki, Y., Takasu, K., Kondo, T. and Kameyama, M.: Platelet hyperaggregability as a risk factor of penetrating artery infarction. Acta 
動脈硬化 Vol. 12 No. 5 December 1984

Neurol. Scand., (suppl. 72): 610-611 (1979).

18) Neri Serneri, G. G., Gensini, G. F., Abbate, R., Mugnaini, C., Favilla, S., Brunelli, C., Chierchia, S. and Parodi, O.: Increased fibrinopeptide A formation and thromboxane $\mathbf{A}_{2}$ production in patients with ischemic heart disease, Relationships to coronary pathoanatomy, risk factors and clinical manifestations. Am. Heart J., 101: 185-194 (1981). 


\title{
Summary
}

\section{Trend of Platelet Function in Arteriosclerotic Diseases by Multivariate Analysis}

\author{
Takashi Fujimoto, Toshimasa Migita, Ryuichi Matsuo, Yasuo Tanaka, \\ Nobuhiko IshidA, Yoshiyuki BabA, Tomio InOUe, Hideaki SaTOH, \\ Yoshihiko SATOH and Toshio TOHNO
}

The Department of Gerontology, Kyorin University School of Medicine, Tokyo

Platelet function was studied comparatively by means of multiple comparison (Scheffe), for which used, as an arteriosclerotic group, were cases of effort angina (33), myocardial infarction (32) and cerebral infarction (25), totalling 90 , their ages averaging $65.8 \pm 10.1$, as the internal samples, and 50 cases of normal healthy subjects group, their ages averaging $48.3 \pm 3.2$, as controls. Next, relationship between the value of the platelet function test and the risk factor of individual patients which is presumed to exert influence on the former was studied by the multivariate analysis, and then an estimate formula for the value of platelet function test was prepared by the use of the risk factor. The formula was applied continually to total 30 cases of arteriosclerotic diseases, and the following results were obtained. As platelet function tests, platelet aggregation (Pl-Ag), thromboxane $\mathbf{B}_{2}$ $\left(\mathrm{TXB}_{2}\right)$, 6-keto-prostaglandin $\quad \mathrm{F}_{1 \alpha} \quad$ (6-KetoPGF $\left._{1 \alpha}\right), \beta$-thromboglobulin $(\beta$-TG) and platelet factor 4 (PF4) were examined.

1. All the diseases in the arteriosclerotic group except effort angina showed higher values of $\mathrm{Pl}-\mathrm{Ag}$, $\mathrm{TXB}_{2}, \beta-\mathrm{TG}, \mathrm{PF} 4$ than those of the normal healthy subjects group, but no significant difference was observed in 6-Keto-PGF $1 \alpha$

2. Regarding mutual relationship between platelet function tests, good correlationships were observed between $\mathrm{TXB}_{2}$ and $\mathrm{TXB}_{2} / 6-\mathrm{Keto}-\mathrm{PGF}_{1 \alpha}$ and between $\beta$-TG and PF4 both in the normal healthy subjects group and arteriosclerotic group.

3. It was found that sex, age and blood pressure are important as the patients' background factors which exert influence on the value of platelet function test.

4. As a result of applying the estimate formula for the value of platelet function test obtained to the subsequent cases, relatively satisfactory results were obtained confirming the reasonability of the estimate formula.

Thus, it was presumed that the correlation of risk factor of individual patients with arteriosclerotic diseases with platelet function alone is weak, but that total judgement of these test items by putting importance to them enables us to know platelet function almost correctly which is found to be of significance.

Key words: Multivariate analysis, Platelet functions, Arteriosclerotic diseases. 